\title{
PRIMARY PERINEAL POSTERIOR HERNIA. AN ABDOMINOPERINEAL APPROACH FOR MESH REPAIR OF THE PELVIC FLOOR
}

\author{
Mara R. Salum, Marisa H. Prado-Kobata, Sarhan S. Saad and Delcio Matos
}

SALUM MR et al. Primary perineal posterior hernia. An abdominoperineal approach for mesh repair of the pelvic floor. CLINICS 60(1):71-74, 2005.

Spontaneous development of perineal hernias is a very rare condition and many techniques have been described for repairing the floor defect.

The authors describe the use of a combined approach in the surgical treatment of primary perineal hernias, by reconstructing the muscle pelvic floor and restoring the rectum to its sacral position with mesh repair. The case of one patient with a huge primary perineal hernia is reported, with clinical manifestations of progressive bulging in the buttock area, obstipation and fecal incontinence.

Long-term follow-up has shown no recurrence of the condition and normal bowel function.

It is concluded that primary perineal hernia can be repaired by a combined surgical approach, by using prosthetic material.

KEYWORDS: Perineal hernia. Abdominoperineal approach. Rectopexy. Pelvic floor hernia. Mesh repair.

Spontaneous development of perineal hernias is a very rare condition and many techniques have been described for repairing the pelvic floor defect. This case report of a patient with a substantial primary perineal hernia details the clinical aspects, emphasizing the advantage of a combined approach. Reduction of the hernia, dissection of the peritoneal sac, careful muscle repair and adequate positioning of the polypropylene mesh are important keys to surgical success.

\section{CASE REPORT}

A 68-year-old healthy white female presented with a twoyear history of posterior perineal bulging that caused discomfort and prevented her from sitting down comfortably. It was associated with obstipation and fecal incontinence. She

From the Department of Gastroenterological Surgery, UNIFESP Escola Paulista de Medicina - SãoPaulo/SP, Brazil.

E-mail: dmatos.dcir@epm.br

Received for publication on May 17, 2004.

Accepted for publication on August 17, 2004. had no history of perineal surgical procedures nor of vaginal deliveries. Perineal examination showed a herniation of a $22 \mathrm{~cm} \times 16 \mathrm{~cm}$ in the right buttock and intestinal peristalsis could be seen and heard using a stethoscope. Digital anal examination showed a normal anal canal and a laterally displaced rectum. A defect in the levator ani musculature, along the posterior-lateral wall of the rectum on the right side, could be observed. The mass could be partially reduced into the pelvis through the pelvic floor by means of manipulation using both hands (Fig. 1). Anal manometry showed that the pressure was discretely lower when at rest and that the sphincters were symmetrical.

Barium enema showed a perineal herniation with looping of the sigmoid colon, upper and middle rectum into the hernial sac (Fig. 2). Computerized tomography (CT) scan and magnetic resonance imaging (MRI) of the lower pelvis showed a large mass protruding through the ischiorectal fossa and perineal region, containing herniated loops of sigmoid colon and part of the rectum. The right levator ani muscle could not be identified. 


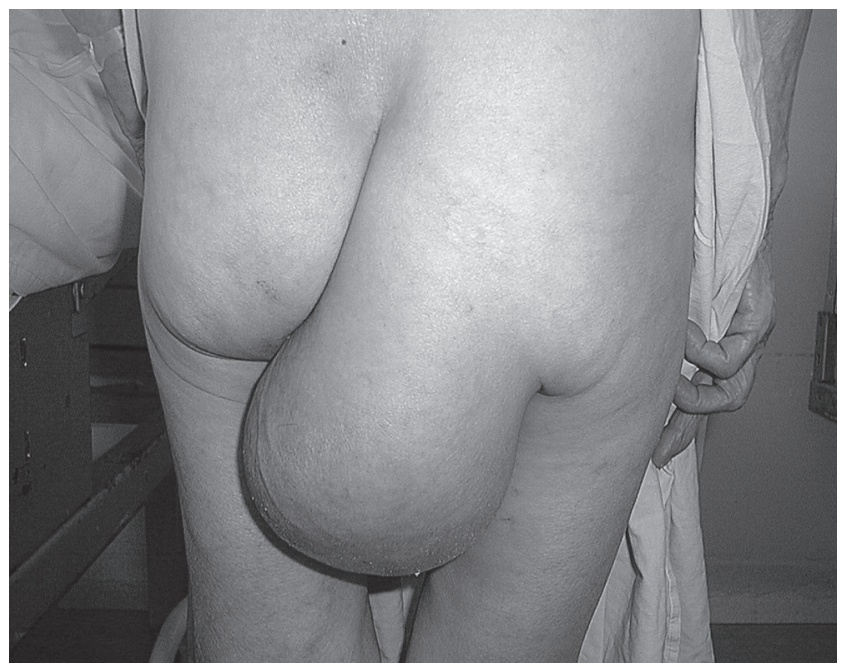

Figure 1 - An enlarging herniation in the right buttock area, partially reducible.

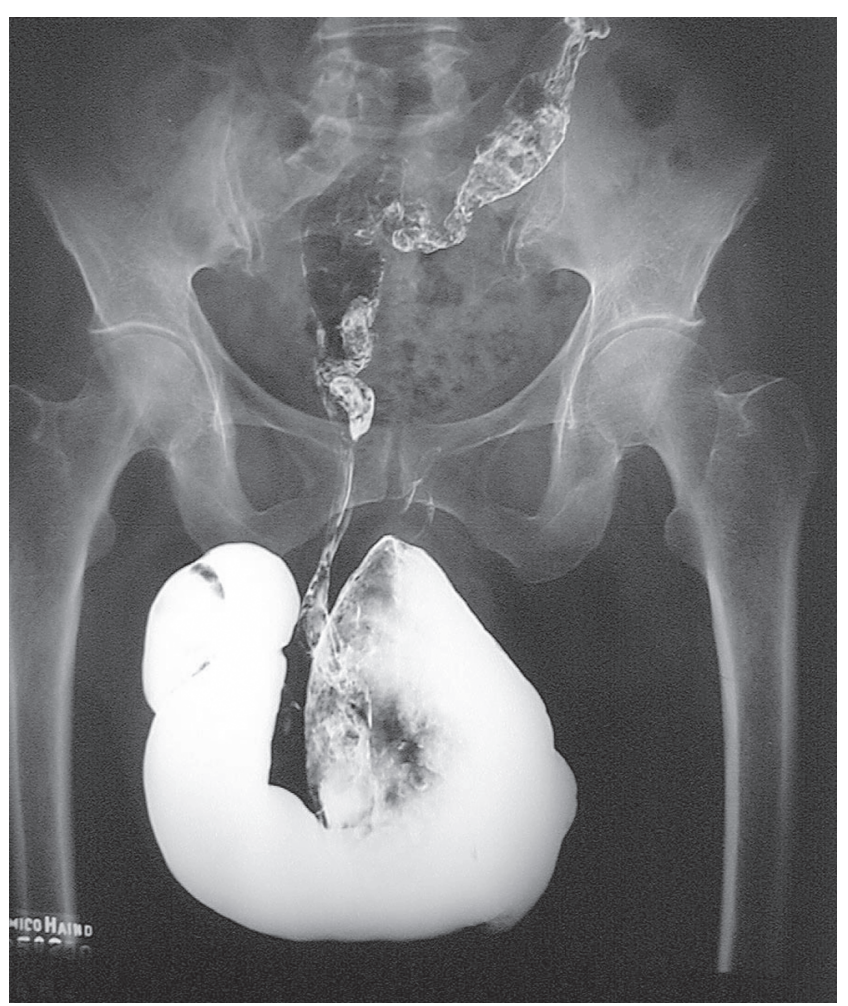

Figure 2 - Barium enema showing a perineal herniation with looping of the sigmoid colon into the hernial sac.

After mechanical bowel preparation and the administration of IV prophylactic antibiotics the operation was carried out under a general anesthetic; an elliptical $12 \mathrm{~cm}$ perianal incision was made across the hernia and the excess skin was excised. The hernial sac was identified via the perineal access, and the sigmoid loop and small bowel could easily be dissected off the sac. A $7 \times 5 \mathrm{~cm}$ polypropylene mesh was sutured across the defect using 3-0 prolene stitches.
Through an abdominal approach, the rectum was restored to its sacral position by posteriorly suturing another $5 \times 3$ $\mathrm{cm}$ polypropylene mesh using 3-0 prolene stitches. A vacuum drain was inserted and the skin was closed using interrupted vicryl 3-0 stitches. The patient was discharged uneventfully from hospital on the sixth day after the operation.

Five years on, the patient has had no fecal incontinence, nor any evidence of perineal hernia recurrence. She has been moving her bowels regularly with no need for assistance.

\section{DISCUSSION}

Posterior primary perineal hernias are very unusual findings and they may be congenital or acquired. They occur most commonly between the ages of 40 and 60 years and are five times more common in females than in males, due to the broader female pelvis and attenuation of the pelvic floor during pregnancy ${ }^{1}$. Signs and symptoms are confined to complaints of a mass in the perineum or buttock, which may cause some discomfort when sitting. The classic signs of hernia, such as perineal bulging, size that varies when abdominal pressure is applied, tympanites and peristalsis, allow diagnosis to be made. However, perineal hernias may be mistaken for other diseases of the perineum and adjacent organs, such as lipomas, fibromas, rectocele, cystocele and prolapse of the rectum. One particular condition from which perineal hernias must be distinguished is sciatic hernia, the rarest of all hernias, which emerges through the greater or lesser sacrosciatic foramen and, like a posterior perineal hernia, presents as a mass along the inferior margin of the gluteus maximus muscle. However, when a perineal hernia is reduced, the direction of reduction together with the palpable defect in the pelvic floor identifies the hernia as perineal rather than sciatic ${ }^{2}$.

The sharp turn to the right of the rectal canal that was seen in the rectal examination of the present case was probably the cause of this patient's difficulty in defecating and the overflow incontinence, considering that no significant alteration was found during preoperative physiological examination. This interpretation of the clinical, imaging and physiological findings is logical and interesting. It is based upon the deep anatomical alterations of the structures of the pelvic floor, combined with the displacement of the sigmoid colon and part of the rectum. The muscle defect can be regarded as the starting point for the entire pathological process.

Radiographic demonstration of such hernias via plain film or barium had already been reported before the advent of CT scanning. They can show that the herniation of the sigmoid colon is adjacent to the distal rectum and going 
into the buttock. In the normal pelvis, CT scans are adequate to display the muscle anatomy of the pelvic floor, thereby allowing the identification of any muscle perineal defect ${ }^{3}$. In the present case, however, CT scan and magnetic resonance imaging of the pelvis did not add more information than was provided by normal radiological examination.

Although simple closure of the pelvic defect by bringing together the levator ani muscles along the midline is occasionally feasible, the pelvic floor is usually deficient and requires support using autogenous or prosthetic materials $^{4}$. The perineal approach is usually difficult in the repair of perineal hernias, unless these are accompanied by an abdominal access. Repair of these hernias is a challenging surgical problem, therefore various methods have been described, but the ideal approach has yet to be established ${ }^{5,6}$. A new laparoscopic approach for repairing postoperative perineal hernias, involving the use of synthetic mesh, has recently been reported and regarded as safe and effective ${ }^{7}$. Although most authors prefer to repair primary perineal hernias through an abdominal incision, we think that a combined approach has many advantages. It is useful for facilitating the removal of excessive skin and subcutaneous tissue after repair of the defect, particularly in the case of postoperative hernia ${ }^{1}$. In the present case, we placed a synthetic mesh graft over the muscle defect and sutured this to the ligamentous and bony borders of the pelvis. The restoration of the rectum to its sacral position was achieved by suturing a piece of the polypropylene mesh to the posterior sacral periosteum.

Considering all the relevant facts from this experience, we have come to the conclusion that, in cases of primary perineal hernias, the combined approach may be useful in the reconstruction of the pelvic floor muscle, by allowing the sewing of mesh reinforcement both from above and below.

\section{RESUMO}

SALUM MR e col. Hérnia perineal posterior primária. Um acesso abdômino-perineal para o reforço do assoalho pélvico com tela. CLINICS 60(1):71-74, 2005.

O desenvolvimento espontâneo de hérnia perineal representa uma condição patológica muito rara.Várias técnicas têm sido descritas para a correção da falha no assoalho muscular pélvico.

Os autores descrevem um acesso cirúrgico combinado para o tratamento das hérnias perineais primárias, pela reconstrução do assoalho pélvico muscular e reposicionamento do reto com reforço utilizando-se tela. $O$ caso de uma paciente com uma volumosa hérnia na região perineal, ca- racterizada como primária, é relatado, evidenciando-se manifestações clínicas de aumento progressivo do saco herniário, dificuldades para evacuar e incontinência fecal.

O seguimento clínico a longo prazo, após a correção cirúrgica, demonstrou que não houve recidiva da hérnia, normalizando-se a função intestinal.

Conclui-se que as hérnias perineais primárias podem ser tratadas por este acesso combinado, utilizando-se próteses.

UNITERMOS: Hérnia perineal primária. Retopexia. Acesso abdômino-perineal. Hérnia do assoalho pélvico. Reforço com tela. 


\section{REFERENCES}

1. Rebecca LC, Richard MP, Garnet JB, Thorson A, Cristensen MA. Rare pelvic floor hernias. Report of a case and review of the literature. Dis Colon Rectum 1992;35:604-612.

2. Thomford NR, Sherman NJ. Primary perineal hernia. Dis Colon Rectum 1969;12:441-443.

3. Lubat E, Gordon RB, Birbaum BA, Megibow AJ. CT diagnosis of posterior perineal hernia. AJR 1990; 154:761-762.

4. Sarr MG, Stewart JR, Cameron JC. Combined abdominoperineal approach to repair of postoperative perineal hernia. Dis Colon Rectum 1982;25:597-599.
5. Beck DE, Fazio VW, Jagelman DG. Postoperative perineal hernia. Dis Colon Rectum 1987;30:21-24.

6. So JB, Palmer MT, Shellito PC. Postoperative perineal hernia. Dis Colon Rectum 1997;40:954-957.

7. Ghelai AM, Islam S, Stoker ME. Laparoscopic repair of postoperative perineal hernia. Surg Laparosc Endosc Percutan Tech 2002;12:119-121. 